\title{
Museums and their audience: towards dialogic communication through social media?
}

\author{
Marco Contri \\ Department of Economics and Management, \\ University of Pisa, \\ Via Cosimo Ridolfi 10, 56124 Pisa, Italy \\ Email: marco.contri@phd.unipi.it
}

\begin{abstract}
Social media (SM) platforms are gaining a leading role as a communication tool for museums, representing an important tool which these institutions can use to engage with their audience. Despite the strategic potential of SM, most museums exhibit a low level of social activity and are still in a phase of monologic communication with their public. In this vein, the present paper aims to investigate whether the top 3 most visited museums in Europe with an official profile on Facebook, namely the Louvre, the British Museum and Tate Modern, use this social platform merely as a marketing tool, or if, on the contrary, they exploit its potential to establish two-way (i.e., dialogic) communication. The results of the analysis show that, although the museums in question are turning to SM increasingly often, their approach continues to be exclusively communicational; indeed, the interactions between the museums and their public are very limited.
\end{abstract}

Keywords: dialogic communication; social media; Facebook; museums.

Reference to this paper should be made as follows: Contri, M. (2020) 'Museums and their audience: towards dialogic communication through social media?', Int. J. Digital Culture and Electronic Tourism, Vol. 3, No. 1, pp.22-35.

Biographical notes: Marco Contri is a Ph.D. Student in Business Administration and Management at University of Pisa.

\section{Introduction}

Social media (SM) can be defined as "a group of internet-based applications that build on the ideological and technological foundations of Web 2.0, and that allow the creation and exchange of user generated content" [Kaplan and Haenlein, (2010), p.61]. Therefore, regardless of the different types of SM (Zarrella, 2010), the main feature of these applications is that they allow users to act not simply as users, but also as co-creators of digital content (Capriotti et al., 2016).

For this reason, SM - and more in general the digital technologies - have revolutionised communication processes (Castells, 2007, 2010), offering new alternatives of communication based on users' involvement and active participation (Baker, 2017). By doing so, social platforms have facilitated the transition from 'one-to-many' interactions, which are typical of traditional media (such as radio, press and TV), to 
'many-to-many' interactions, making the communication 'multi-directional' and therefore facilitating the development of more symmetrical interactions (Castelló et al., 2013). In this sense, the advent of Web 2.0 has not only reorganised the way in which organisations can gather information, but has also redefined stakeholders' expectations (Bonsón and Ratkai, 2013). For this reason, strategies related to the internet have seen a substantial shift, from a primary focus on information to a focus on communication and cooperation (Fuchs, 2008; Kent and Taylor, 2002).

This change of communication model has interested all kinds of organisations, including non-profit entities (Bellucci and Manetti, 2017) such as - in particular museums (Capriotti and Kuklinski, 2012).

Regarding museums, SM platforms are gaining a leading role as a communication tool (Suzić et al., 2016). Nowadays, these institutions operate in an increasingly competitive environment, where competition involves not only other museums and cultural institutions, but also organisations belonging to educational and entertainment industries (López et al., 2018; Burton and Scott, 2003; Kotler et al., 2008). Survival in this competitive arena requires the right management decisions, as well as the development of an interactive or dialogic form of communication (Capriotti et al., 2016) in order to increase the level of interaction between museums and their public (Camarero et al., 2016).

In this respect, SM platforms seem to have the potential to establish the ideal conditions to favour dialogic communication, which represents the framework for the building of lasting relationships between organisations and their audience via the web (Kent and Taylor, 2002; Pang et al., 2018). Notwithstanding, some studies have highlighted that museums do not always take advantage of the opportunities of dialogue provided by SM (Capriotti and Losada-Díaz, 2018).

In light of these considerations, the present paper aims to investigate whether the top 3 European museums (in terms of visits) employ Facebook (FB) - the most used SM platform in the world (Statista, 2019) - as a tool for one-way communication, with the sole goal of sharing information related to museums' activities (in other words, merely as a marketing tool), or if, on the contrary, they exploit the potential of this social platform to establish two-way (i.e., dialogic) communication.

The remainder of the paper is organised as follows. Section 2 includes the literature review of SM and dialogic communication, while Section 3 illustrates the research methodology. Section 4 puts forth the empirical results and discusses the findings of this study. The paper ends with conclusions regarding the use of SM as a tool for supporting dialogic communication in Section 5.

\section{Theoretical background}

Digital technologies and, in particular, the advent of SM, have deeply impacted museums, forcing them to find innovative solutions to the changing technological environment (Kotler et al., 2008). The field of public relations has also seen a theoretical shift for museums, from one-way communication to an emphasis on relationship building through dialogue (Waters et al., 2011).

From this perspective, online communication represents an ideal avenue for fostering dialogic communication, which refers to a process of two-way discussion using internet 
tools where participants are able to exchange information, comments, opinions, assessment and experiences on a continuous basis (Kent and Taylor, 1998, 2002).

Kent and Taylor (1998) identified five principles which organisations may follow to promote interaction with online users. These principles include:

a the 'dialogic loop'

$\mathrm{b}$ the usefulness of information

c the generation of return visits

d the intuitiveness/ease of interface

e the conservation of visitors.

According to Capriotti and Kuklinski (2012), nowadays the dialogic loop represents not merely a principle, but also the result of the correct management of the other four principles. Furthermore, the same authors grouped the four remaining principles into two clusters: 'content management' (principles of usefulness of information and intuitiveness/ease of interface), related to the type of information provided and how it is organised online, and 'interaction management' (principles of generation of return visits and conservation of visitors), connected to the level of interaction between organisations and their public (Table 1).

Table 1 Principles of effective dialogic communication

\begin{tabular}{|c|c|c|}
\hline & Principles & Description \\
\hline \multirow[t]{2}{*}{$\begin{array}{l}\text { Content } \\
\text { management }\end{array}$} & $\begin{array}{l}\text { The usefulness of } \\
\text { information }\end{array}$ & $\begin{array}{l}\text { Organisations should provide the information which is } \\
\text { useful for users and specifically tailored to their needs. }\end{array}$ \\
\hline & $\begin{array}{l}\text { The intuitiveness/ } \\
\text { ease of interface }\end{array}$ & $\begin{array}{l}\text { Organisations should present digital content in such a way } \\
\text { that users are able to easily to find it. }\end{array}$ \\
\hline \multirow[t]{3}{*}{$\begin{array}{l}\text { Interaction } \\
\text { management }\end{array}$} & $\begin{array}{l}\text { The generation of } \\
\text { return visits }\end{array}$ & $\begin{array}{l}\text { Organisations should use appealing pages, with features } \\
\text { that make them attractive for repeat visits over time } \\
\text { (updated information, online forums, etc.). }\end{array}$ \\
\hline & $\begin{array}{l}\text { The rule of } \\
\text { conservation of } \\
\text { visitors }\end{array}$ & $\begin{array}{l}\text { Organisations should organise their social pages to keep } \\
\text { visitors on the site/social platform, rather than leading } \\
\text { them off to third-party websites. }\end{array}$ \\
\hline & The 'dialogic loop' & $\begin{array}{l}\text { Following the above-mentioned principles, organisations } \\
\text { have the potential to create an ongoing dialogue with their } \\
\text { virtual audience, allowing the public to ask questions and } \\
\text { the organisation to respond. }\end{array}$ \\
\hline
\end{tabular}

Scholars initially examined dialogic communication via traditional websites, both of companies (Park and Reber, 2008) and non-profit organisations (Ingenhoff and Koelling, 2010; Taylor et al., 2001), following which they adapted the principles of dialogic communication to social platforms, such as Facebook, Twitter and YouTube (Bortree and Seltzer, 2009; DiStaso and McCorkindale, 2013; Rybalko and Seltzer, 2010).

In the context of museums, some studies highlighted that SM platforms have great potential as a dialogic communication medium because they include some dialogic 
features by default (Capriotti and Losada-Díaz, 2018; Zafiropoulos et al., 2015) that allow for the exchange of information, debate, discussion and collaboration (Kidd, 2011). As noted by Avery et al. (2010, p.337), "social media are inherently interactive, communicative, and social." Furthermore, SM could be particularly useful for non-profit organisations - such as museums - which have limited funds and human resources compared to firms (Waters et al., 2009). Moreover, for these reasons, Suzić et al. (2016) recognised the need for museums to use SM in a strategic way and to develop an effective SM strategy.

However, despite the strategic potential of SM, several studies have found that most museums exhibit a low level of SM activity and are still in a phase of monologic communication with their public (Capriotti and Kuklinski, 2012). In this case, institutions do not fully exploit the dialogic features of SM (Kim et al., 2014) and use these tools only to support their marketing strategies in the following ways: promotion and communication, word of mouth, market research and innovation management and reputation management (Hausmann, 2012a; Kotler et al., 2008; Mangold and Faulds, 2009). Furthermore, other studies have highlighted that there are significant differences in the use of SM tools among countries; indeed, most European museums do not use digital tools to actively promote dialogue with users (Badell, 2015), while American museums are trying to increase their use of SM for multi-way communication strategies (Fletcher and Lee, 2012).

In the light of the above, our research question involves determining whether or not the top 3 most visited museums in Europe use FB as a tool for encouraging a more interactive and collaborative dialogue with their audience and therefore for supporting dialogic communication.

\section{Methodology}

Considering that interaction is the cornerstone on which dialogic communication is built, this exploratory research aims to analyse the level and the type of interaction between museums and users on SM. In particular, the analysis focuses on the 3 most visited museums in Europe (TEA/AECOM, 2017) with an official profile on Facebook, namely the Louvre (Paris), the British Museum and Tate Modern (London). ${ }^{1}$ These institutions are in first, third and fourth place respectively in the ranking, while the Vatican Museums (Vatican City) are in second place but are active only on TripAdvisor and YouTube (Table 2). ${ }^{2}$

The focus on FB can be justified considering that it is not only the most adopted form of SM among artistic and cultural organisations [Thomson et al., (2013), pp.25-26], but also the most popular social network worldwide, followed by YouTube and Instagram (Statista, 2019). Indeed, FB has approximately 2.3 billion monthly active users, against the 1.9 billion of YouTube and the 1 billion of Instagram (Hootsuite, 2019). Furthermore, FB is a 'community relationships' channel, whereas YouTube and Instagram are 'community interests' tools (Ang, 2011), and therefore the former is particularly suitable for dialogic communication (Bellucci and Manetti, 2017). This could explain why most studies that apply principles of dialogic communication to SM focus on FB and explore its communicative potential for building dialogic relationships (Wirtz and Zimbres, 2018). 
Table 2 Museums and SM

\begin{tabular}{llcccccc}
\hline \multirow{2}{*}{$\begin{array}{l}\text { Place in } \\
\text { the ranking }\end{array}$} & Museums & \multicolumn{5}{c}{ Social platforms } \\
\cline { 2 - 7 } & Facebook & Twitter & Instagram & Pinterest & YouTube & Others $^{*}$ \\
\hline 1 & Louvre & $\checkmark$ & $\checkmark$ & $\checkmark$ & & $\checkmark$ & \\
2 & $\begin{array}{l}\text { Vatican } \\
\text { Museums }\end{array}$ & & & & $\checkmark$ & $\checkmark$ \\
3 & $\begin{array}{l}\text { British } \\
\text { Museum }\end{array}$ & $\checkmark$ & $\checkmark$ & $\checkmark$ & $\checkmark$ & $\checkmark$ & $\checkmark$ \\
4 & Tate & $\checkmark$ & $\checkmark$ & $\checkmark$ & $\checkmark$ & $\checkmark$ & \\
\hline
\end{tabular}

Note: *the residual category 'others' includes TripAdvisor (Vatican Museums), Google+ and RSS (British Museum).

In order to answer our exploratory research question, we designed a content analysis (Krippendorff, 2012) that took into account the FB page of the Louvre, the British Museum and Tate galleries. The study was developed in two steps, with the aim of exploring two fundamental aspects of online communication, namely the content of the social activity and then the interaction on FB (Camarero et al., 2016).

In the first step, the content of each post published by the museums in the first three months of the year 2019 (1st January 2019-31st March 2019) was grouped into one of the following categories:

- $\quad$ art-historical content

- information on current or upcoming exhibitions and events

- information on extraordinary activities, such as restorations, artworks on loan or other forms of collaboration with other museums or institutions

- invite to support museum's activities and initiatives

- opening hours

- $\quad$ others, which is a residual category for those posts that do not fit into other classifications.

Following this, we also investigated how many posts contained pictures, audio/video or links, that is, the richness of museums' social efforts (Chung et al., 2014). Several studies have highlighted that posts containing these tools are more informative and are more likely to be noticed and shared by users (Emerson, 2012). Indeed, these digital tools help the museums' stakeholders to understand information, and in this sense also allow them to fulfil the principle of usefulness of information (Kent and Taylor, 1998).

In the second phase, we conducted a descriptive analysis of the posts in order to explore the interaction between museums and their public. This practice of gathering and analysing data from SM ('SM analytics') is widely employed in literature for evaluating the online interaction (Gerrard et al., 2017; Stieglitz et al., 2014) between organisations companies (DiStaso and McCorkindale, 2013) and non-profit entities (Bellucci and Manetti, 2017) like museums (Capriotti and Losada-Díaz, 2018) - and stakeholders. Therefore, we manually collected the number of 'likes', 'shares', and 'comments' for every single post in each category. A high number of likes, shares and comments suggests indeed a reasonable level of interaction between museums and their audience 
(Manetti et al., 2017). At the same time, since museums can also reply to users' comments, we also evaluated whether and how frequently this type of two-way communication really happened, thereby exploring whether museums exploit the dialogic potential of FB. Furthermore, following a similar approach to that adopted by Bellucci and Manetti (2017), we also investigated the general tenor of the discussion between the museums and the public, indicating whether feedback from users was more positively-orientated (compliments, constructive proposals, etc.), negatively-orientated (protests, constructive criticism, etc.) or neutral. In order to achieve this, we classified each reply with a value ranging from 1 (protest) to 3 (compliments), with neutral comments receiving a score of 2 . In addition to analysing single posts, we also collected the value of 'page likes' for every FB page, which can be seen a measure of the museum's virtual audience.

\section{Results and discussion}

This study focuses on the Louvre, the British Museum and Tate galleries, which are the most visited European museums and among the most popular worldwide (TEA/AECOM, 2017). These institutions joined FB in 2008, 2009 and 2007 respectively, and have on staff professionals who deal with SM.

The first step of this research takes into account the content of the social activity of the museums under study and, in particular, the level of activity and the richness of the content, both of which are important aspects when it comes to attracting users' attention (Moro et al., 2016).

First of all, the study investigates how many posts the museums have published during the period of analysis, since a high level of posting activity is expected to offer more opportunities for interaction and therefore for relationship building (Vlachvei and Kyparissis, 2017). For this reason, Hausmann (2012b) recommended updating social profiles several times per day. The results reveal that Tate galleries have published an outstanding number of posts (186) compared to the Louvre (63) and the British Museum (67) (Table 3). In this sense, the last two institutions, having posted approximately five posts per week, surprisingly exhibit low posting activity (Capriotti and Losada-Díaz, 2018), although they are in first and third place respectively in the ranking of the most visited European museums (TEA/AECOM, 2017). Therefore, these institutions should increase the number of posts which they put up in order to encourage dialogue with their audience. On the contrary, Tate galleries have daily activity on their FB account, posting about two messages every day and hence partially following Hausmann's recommendation.

Considering the different kinds of content of the messages which museums deliver on their official FB accounts, the analysis finds that art-historical information (133 posts out of 316) and information about current or upcoming exhibitions and events (131) are the most common categories (Table 3). This is an interesting result because the success of museums in enhancing dialogue and engaging users is positively affected if published posts include content which focuses on educational information in addition to the usual promotional messages (Suzić et al., 2016). Indeed, as Hausmann (2012b) noted, the more appealing the content is, the more dialogue there will be between museums and users. Furthermore, it is worth noting that, surprisingly, only the Louvre has published posts to 
invite the public to support its activities and initiatives. In particular, the museum invited users to join the 'Société des Amis du Louvre', which is the main private supporter of the museum, and to support the restoration and conservation project of the 'Arc de Triomphe du Carrousel' (Paris). In this respect, many studies have indeed highlighted the opportunities provided by the internet to find donors and to create a network of supporters (Anderson and de Mille, 2006; Kotler et al., 2008).

Table 3 Results of content analysis by museums and types of content

\begin{tabular}{lcccc}
\hline \multirow{2}{*}{ Content of post } & \multicolumn{4}{c}{ No. of posts } \\
\cline { 2 - 5 } & Louvre & British Museum & Tate & Tot. \\
\hline Art-historical content & 18 & 39 & 76 & 133 \\
Current or upcoming exhibitions and events & 24 & 22 & 85 & 131 \\
Extraordinary activities & 5 & 4 & 13 & 22 \\
Invite to support museum's activities and initiatives & 5 & - & - & 5 \\
Opening hours & 5 & - & - & 5 \\
Others & 6 & 2 & 12 & 20 \\
Tot. & 63 & 67 & 186 & 316 \\
\hline
\end{tabular}

Figure 1 Tools used in the posts by museums

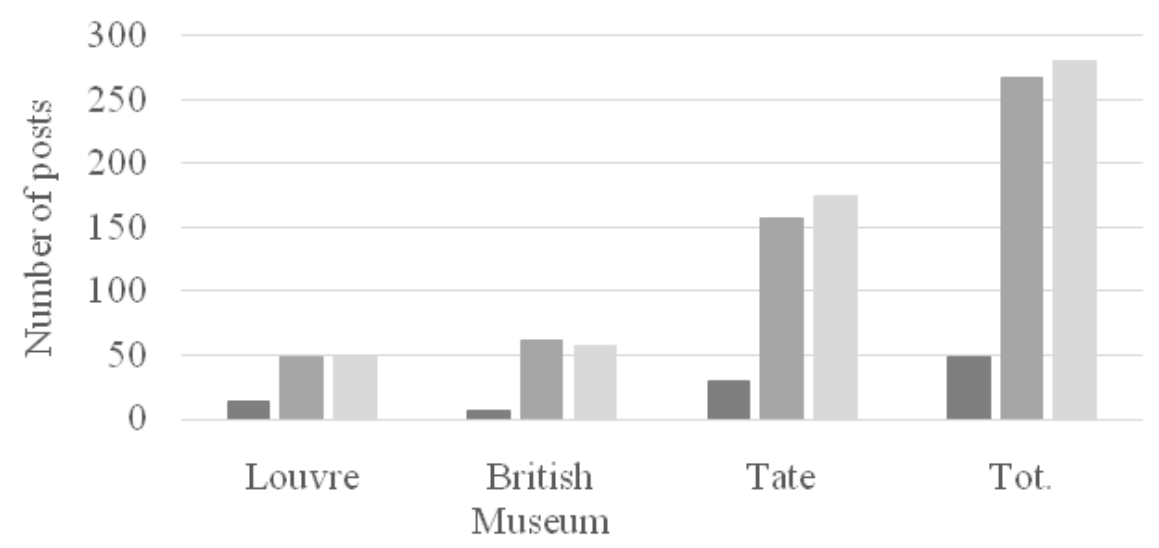

घVideo $\square$ Photo/Image $\backsim$ Link

As regards the richness of museums' social efforts (Chung et al., 2014), this study shows that the vast majority of the posts include - in addition to text - links (281 posts out of the 316 total) and photos (267), and only in some cases audio or video (49) (Figure 1). This result is particularly interesting considering that interactive links to other social platforms or websites and images increase the users' propensity to look at the content of the messages (Sabate et al., 2014); indeed, in this sense, said links and images have the potential to foster the interaction and therefore the dialogue between museums and users (Emerson, 2012). 
When examining more-in-depth the level of interaction on $\mathrm{FB}$, it is necessary to observe - first of all - the 'page total likes', which can be seen as a measure of the virtual audience, indicating how many users are interested in the museums' initiatives (Suzić et al., 2016). The Louvre, the British Museum and Tate galleries have an outstanding number of fans: 2,478,220, 1,503,979 and 1,176,163, respectively (Table 4). Said values confirm the great appeal of these institutions, especially when looking at the number of followers of the other institutions included in the ranking of the top 10 museums for fans on FB (TEA/AECOM, 2017).

Table 4 The 10 most visited European museums and their audience on FB

\begin{tabular}{llc}
\hline Museums & & No. of FB page likes \\
\hline Louvre & Paris, France & $2,478,220$ \\
British Museum & London, UK & $1,503,979$ \\
Tate & London, UK & $1,176,163$ \\
National Gallery & London, UK & 946,958 \\
Natural History Museum & London, UK & 488,759 \\
State Hermitage & St Petersburg, Russia & 58,162 \\
Reina Sofia & Madrid, Spain & 380,892 \\
Victoria \& Albert Museum & London, UK & 657,604 \\
Centre Pompidou & Paris, France & 679,802 \\
Mean & & $1,004,733$ \\
Standard deviation & & 756,358 \\
\hline
\end{tabular}

Regarding likes, shares and comments, the analysis points out that the content most frequently published by museums (art-historical information and information about current or upcoming exhibitions and events) is also the content which is most appreciated by users (Table 5). Nevertheless, the study reveals that fans mainly react to posts by using 'like', whereas 'share' and especially 'comment' are used to a lesser extent. This means that, if it is true that a high number of likes, shares, and comments suggests a potentially wider level of interaction between museums and users, the lower values related to the comment tool seem to suggest a contained dialogue among participants.

In order to provide a further confirmation of this preliminary evidence, the present study also explored the replies that were posted by museums, finding that in very few cases these institutions did reply to users' comments. Out of a total of 16,039 comments, only 24 are replies by museums (more specifically, 10 by the British Museum, 7 by the Louvre and 7 by Tate galleries). Furthermore, the general tenor of the dialogue between the museums and the public is substantially neutral (2.1), with most comments containing merely information requests. Therefore, the analysis shows that these museums rarely take part in discussion, thereby not optimally exploiting the communicative opportunities which FB offers in order to create a real two-way communication with their audience (Suzić et al., 2016). In sum, and consistent with Langa (2014), the findings confirm that the mere use of digital tools does not necessarily result in more engagement of, and dialogue with, the online audience. 
Table 5 Likes, shares and comments by museums and types of content

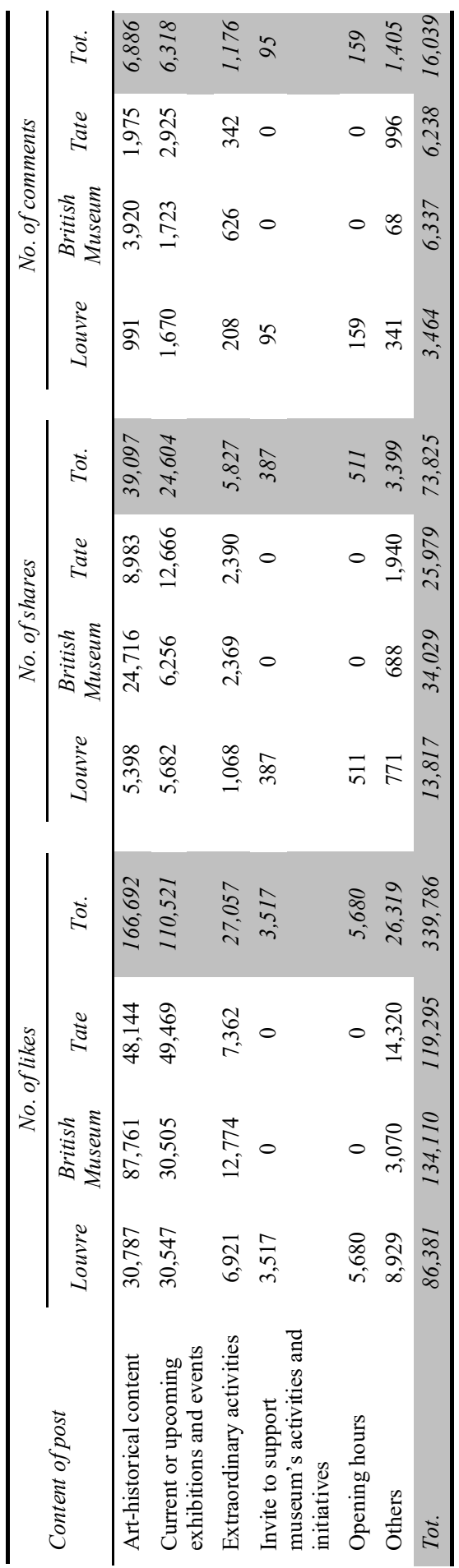




\section{Conclusions}

Digital technologies have the potential to deeply change how museums engage with their audience (Capriotti and Losada-Díaz, 2018), allowing them to receive real-time feedback about their activities and then to create a more interactive and collaborative approach to communication (Camarero et al., 2016). In this respect, the low-cost opportunities which SM provide for the two-way communication between museums and their audience make them an affordable and promising resource for building strong relationships with the public (Hausmann, 2012b). Nevertheless, the presence of museums on SM might not provide the expected benefits if said presence is not appropriately conceptualised and implemented (Kidd, 2011).

In this vein, the current study explores the use of FB as a tool of dialogic communication in museums, focusing on the three most visited museums in Europe (TEA/AECOM, 2017) with an official profile on Facebook, namely the Louvre (Paris), the British Museum and Tate Modern (London).

The results show that these institutions do not fully take advantage of the dialogic communication features of SM in order to actively foster interaction with users. Considering the content of social activity, the study finds that only Tate galleries have daily posting activity (approximately two posts every day), whereas the Louvre and the British Museum, somewhat surprisingly, post few messages (approximately five posts per week) over the period of analysis (Capriotti and Losada-Díaz, 2018). However, it should be noted that most posts include links and/or photos, which encourage users to pay more attention to content, thereby indirectly favouring the possibility of dialogue between the museums and the public. Nevertheless, regarding the level of interaction, this study points out that fans mainly react to posts through the 'like' function, while 'share' and especially 'comment' are used to a lesser extent; above all, the analysis finds that the museums in question answered only three times, hence suggesting a limited number of opportunities for dialogue between the institutions and their audience.

In sum, and answering the research question, the top 3 most visited museums in Europe do not use FB as a tool for encouraging dialogue with their audience and therefore for supporting dialogic communication. Consistent with the results of other studies (Badell, 2015; Capriotti and Kuklinski, 2012; Russo et al., 2008), these institutions are still in a phase of monologic (one-to-many) communication with their public. For this reason, said museums should redefine the relationship with their online audience (Chung et al., 2014) through the development of a SM strategy elaborated on according to the specific mission and goals of the museums (Suzić et al., 2016).

The current study has at least four limitations which, however, might represent opportunities for further research on this topic. First of all, this is an exploratory research study aimed at providing some initial insight into how (and to what extent) museums use $\mathrm{SM}$ and, most of all, whether they exploit the potential of social platforms in order to establish a dialogic interaction with stakeholders and users. Further studies could employ interviews or surveys administered to the staff (e.g., SM managers) of the museums under study, in order to understand more in depth what museums expect from SM, what their SM strategy is and, most importantly, if they use SM to involve users or if, on the contrary, they are still in a phase of monologic communication with their public.

Second, the period of analysis is limited (only three months), although it is in line with other studies on SM (Gronemann et al., 2015; Suzić et al., 2016). Therefore, it 
would be appropriate to consider a longer period of time in order to obtain a more comprehensive view of museums' social activity.

Third, this study focuses only on FB and, although it is the most popular form of SM (Hootsuite, 2019; Statista, 2019), it could be interesting to broaden the analysis of the dialogic potential of SM to other social platforms, especially Twitter which - like FB - is suitable for dialogic communication (Langa, 2014; Sáez-Martín et al., 2015).

Finally, this paper only takes into account the three most visited European museums; in this respect, future research could extend the analysis to a larger number of institutions, considering - for instance - the ten most visited European museums or the top 10 worldwide museums.

\section{References}

Anderson, E. and de Mille, A. (2006) Fundraising for Museums, AIM Focus Papers, Association of Independent Museums, Gosport.

Ang, L. (2011) 'Community relationship management and social media', Journal of Database Marketing \& Customer Strategy Management, Vol. 18, No. 1, pp.31-38.

Avery, E., Lariscy, R., Amador, E., Ickowitz, T., Primm, C. and Taylor, A. (2010) 'Diffusion of social media among public relations practitioners in health departments across various community population size', Journal of Public Relations Research, Vol. 22, No. 3, pp.336-358.

Badell, J.I. (2015) 'Museums and social media: Catalonia as a case study', Museum Management and Curatorship, Vol. 30, No. 3, pp.244-263.

Baker, S. (2017) 'Identifying behaviours that generate positive interactions between science museums and people on Twitter', Museum Management and Curatorship, Vol. 32, No. 2, pp.144-159.

Bellucci, M. and Manetti, G. (2017) 'Facebook as a tool for supporting dialogic accounting? Evidence from large philanthropic foundations in the United States', Accounting, Auditing \& Accountability Journal, Vol. 30, No. 4, pp.874-905.

Bonsón, E. and Ratkai, M. (2013) 'A set of metrics to assess stakeholder engagement and social legitimacy on a corporate Facebook page', Online Information Review, Vol. 37, No. 5, pp.787-803.

Bortree, D.S. and Seltzer, T. (2009) 'Dialogic strategies and outcomes: an analysis of environmental advocacy groups' Facebook profiles', Public Relations Review, Vol. 35, No. 3, pp.317-319.

Burton, C. and Scott, C. (2003) 'Museums: challenges for the 21st century', International Journal of Arts Management, Vol. 5, No. 2, pp.56-68.

Camarero, C., Garrido, M.J. and San José, R. (2016) 'Efficiency of web communication strategies: the case of art museums', International Journal of Arts Management, Vol. 18, No. 2, pp.42-62.

Capriotti, P. and Kuklinski, H.P. (2012) 'Assessing dialogic communication through the internet in Spanish museums', Public Relations Review, Vol. 38, No. 4, pp.619-626.

Capriotti, P. and Losada-Díaz, J. (2018) 'Facebook as a dialogic communication tool at the most visited museums of the world', El Profesional de la Información, Vol. 27, No. 3, pp.642-650.

Capriotti, P., Carreton, C. and Castillo, A. (2016) 'Testing the level of interactivity of institutional websites: from museums 1.0 to museums 2.0', International Journal of Information Management, Vol. 36, No. 1, pp.94-104.

Castelló, I., Morsing, M. and Schultz F. (2013) 'Communicative dynamics and the polyphony of corporate social responsibility in the network society', Journal of Business Ethics, Vol. 118, No. 4, pp.683-694. 
Castells, M. (2007) 'Communication, power and counter-power in the network society', International Journal of Communication, Vol. 1, No. 1, pp.238-266.

Castells, M. (2010) The Rise of the Network Society, Wiley-Blackwell, Chichester.

Chung, T.L., Marcketti, S. and Fiore, A.M. (2014) 'Use of social networking services for marketing art museums', Museum Management and Curatorship, Vol. 29, No. 2, pp.1-18.

DiStaso, M.W. and McCorkindale, T. (2013) 'A benchmark analysis of the strategic use of social media for Fortune's most admired U.S. companies on Facebook, Twitter and YouTube', Public Relations Journal, Vol. 7, No. 1, pp.1-33.

Emerson, M.F. (2012) Social Media Marketing from A to Z, 7 December [online] https://boss.blogs. nytimes.com/2012/12/07/social-media-marketing-from-a-to-z/ (accessed 8 March 2019).

Fletcher, A. and Lee, M.J. (2012) 'Current social media uses and evaluations in American museums', Museum Management and Curatorship, Vol. 27, No. 5, pp.505-521.

Fuchs, C. (2008) Internet and Society: Social Theory in the Information Age, Routledge, New York.

Gerrard, D., Sykora, M. and Jackson, T. (2017) 'Social media analytics in museums: extracting expressions of inspiration', Museum Management and Curatorship, Vol. 32, No. 3, pp.232-250.

Gronemann, S.T., Kristiansen, E. and Drotner, K. (2015) 'Mediated co-construction of museums and audiences on Facebook', Museum Management and Curatorship, Vol. 30, No. 3, pp.174-190.

Hausmann, A. (2012a) 'The importance of word of mouth for museums: an analytical framework', International Journal of Arts Management, Vol. 14, No. 3, pp.32-43.

Hausmann, A. (2012b) “Creating 'buzz': opportunities and limitations of social media for arts institutions and their viral marketing', International Journal of Nonprofit and Voluntary Sector Marketing, Vol. 17, No. 3, pp.173-182.

Hootsuite (2019) Global Digital Report 2019 [online] http://wearesocial.com/global-digital-report2019 (accessed 6 May 2019).

Ingenhoff, D. and Koelling, A.M. (2010) 'Web sites as a dialogic tool for charitable fundraising NPOs: a comparative study', International Journal of Strategic Communication, Vol. 4, No. 3, pp.171-188.

Kaplan, A.M. and Haenlein, M. (2010) 'Users of the world, unite! The challenges and opportunities of social media', Business Horizons, Vol. 53, No. 1, pp.59-68.

Kent, M.L. and Taylor, M. (1998) 'Building dialogic relationships through the world wide web', Public Relations Review, Vol. 24, No. 3, pp.321-334.

Kent, M.L. and Taylor, M. (2002) 'Towards a dialogic theory of public relations', Public Relations Review, Vol. 28, No. 1, pp.21-37.

Kidd J. (2011) 'Enacting engagement online: framing social media use for the museums', Information, Technology and People, Vol. 24, No. 1, pp.64-77.

Kim, D., Chun, H., Kwak, Y. and Nam, Y. (2014) 'The employment of dialogic principles in website, Facebook, and Twitter platforms of environmental non-profit organizations', Social Science Computer Review, Vol. 32, No. 5, pp.590-605.

Kotler, N.G., Kotler, W. and Kotler, P. (2008) Museum Strategy and Marketing. Designing Missions, Building Audiences, Generating Revenue and Resources, Jossey Bass Wiley, San Francisco.

Krippendorff, K. (2012) Content Analysis: An Introduction to its Methodology, Sage, Thousand Oaks.

Langa, L. (2014), 'Does Twitter help museums engage with visitors?', in iConference 2014 Proceedings, pp.484-495.

López, M.F.B., Virto, N.R. and San-Martín, S. (2018) 'The cornerstones of museum performance. A cross-national analysis', Museum Management and Curatorship [online] https://oi.org/ 10.1080/09647775.2018.1516562 (accessed 4 March 2019). 
Manetti, G., Bellucci, M. and Bagnoli L. (2017) 'Stakeholder engagement and public information through social media: a study of Canadian and American public transportation agencies', American Review of Public Administration, Vol. 47, No. 8, pp.991-1009.

Mangold, G.W. and Faulds, D.J. (2009) 'Social media: the new hybrid element of the promotion mix', Business Horizons, Vol. 52, No. 4, pp.357-365.

Moro, S., Rita, P. and Vala, B. (2016) 'Predicting social media performance metrics and evaluation of the impact on brand building: a data mining approach', Journal of Business Research, Vol. 69, No. 9, pp.3341-3351.

Pang, A., Shin W., Lew, Z. and Walther J.B. (2018) 'Building relationships through dialogic communication: organizations, stakeholders, and computer-mediated communication', Journal of Marketing Communications, Vol. 24, No. 1, pp.68-82.

Park, H. and Reber, B.H. (2008) 'Relationship building and the use of web sites: how Fortune 500 corporations use their web sites to build relationships', Public Relations Review, Vol. 34, No. 4, pp.409-411.

Russo, A., Watkins, J., Kelly, L. and Chan, C. (2008) 'Participatory communication with social media', Curator: The Museum Journal, Vol. 51, No. 1, pp.21-31.

Rybalko, S. and Seltzer, T. (2010) 'Dialogic communication in 140 characters or less: how Fortune 500 companies engage stakeholders using Twitter', Public Relations Review, Vol. 36, No. 4, pp.336-341.

Sabate, F., Berbegal-Mirabent, J., Cañabate, A. and Lebherz, P.R. (2014) 'Factors influencing popularity of branded content in Facebook fan pages', European Management Journal, Vol. 32, No. 6, pp.1001-1011.

Sáez-Martín, A., Haro de Rosario, A. and Caba Pérez, M.D.C. (2015) 'Using Twitter for dialogic communication: local government strategies in the European Union', Local Government Studies, Vol. 41, No. 3, pp.421-444.

Statista (2019) Most Popular Social Networks Worldwide as of January 2019, Ranked by Number of Active Users (in Millions) [online] http://www.statista.com/statistics/272014/global-socialnetworks-ranked-by-number-of-users/ (accessed 6 May 2019).

Stieglitz, S., Dang-Xuan, L., Bruns, A. and Neuberger, C. (2014) 'Social media analytics. An interdisciplinary approach and its implications for information systems', Business and Information Systems Engineering, Vol. 6, No. 2, pp.89-96.

Suzić, B., Karlíček, M. and Stř́teský, V. (2016) 'Social media engagement of Berlin and Prague museums', The Journal of Arts Management, Law, and Society, Vol. 46, No. 2, pp.73-87.

Taylor, M., Kent, M.L. and White, W.J. (2001) 'How activist organizations are using the internet to build relationships', Public Relations Review, Vol. 27, No. 3, pp.263-284.

TEA/AECOM (2017) Theme Index and Museum Index: The Global Attractions Attendance Report [online] http://www.teaconnect.org (accessed 6 May 2019).

Thomson, K., Purcell, K. and Rainie, L. (2013) Arts Organizations and Digital Technologies, Pew Research Center's Internet \& American Life Project, Washington.

Vlachvei, A. and Kyparissis, A. (2017) 'Museums on Facebook wall: a case study of Thessaloniki's museums', Tourismos, Vol. 12, No. 3, pp.75-96.

Waters, R.D., Burnett, E., Lamm, A. and Lucas, J. (2009) 'Engaging stakeholders through social networking: how non-profit organisations are using Facebook', Public Relations Review, Vol. 35, No. 2, pp.102-106.

Waters, R.D., Canfield, R.R., Foster, J.M. and Hardy, E.E. (2011) 'Applying the dialogic theory to social networking sites: examining how university health centers convey health messages on Facebook', Journal of Social Marketing, Vol. 1, No. 3, pp.211-227.

Wirtz, J.G. and Zimbres, T.M. (2018) 'A systematic analysis of research applying 'principles of dialogic communication' to organizational websites, blogs, and social media: implications for theory and practice', Journal of Public Relations Research, Vol. 30, Nos. 1-2, pp.5-34. 
Zafiropoulos, K., Vrana, V. and Antoniadis, K. (2015) 'Use of twitter and Facebook by top European museums', Journal of Tourism, Heritage \& Services Marketing, Vol. 1, No. 1, pp.16-24.

Zarrella, D. (2010) The Social Media Marketing Book, O’Really Media, Sebastopol.

\section{Notes}

1 Tate Modern is a part of Tate galleries, which also comprise Tate Britain, Tate Liverpool and Tate St Ives. These galleries share the same unique profile on FB.

2 Vatican Museums have a FB profile, but the last update dates back to 24 January 2017 and the website does not contain any link to this page. 